\title{
"NÃO TEM CORPO, NÃO TEM CRIME": NOTAS SOCIOANTROPOLÓGICAS SOBRE O ATO DE FAZER DESAPARECER CORPOS
}

\author{
Fábio Alves Araújo* \\ Instituto Federal do Rio de Janeiro - Brasil
}

Resumo: $O$ artigo propõe uma análise socioantropológica sobre o fenômeno do desaparecimento de pessoas. A reflexão é construída a partir do diálogo com o trabalho de outros pesquisadores e com base em material levantado em meu próprio trabalho de campo, que inclui o acompanhamento de coletivos de familiares de vítimas de violência, entrevistas, documentação jornalística, estatísticas criminais, legislação sobre o assunto e boletins de ocorrência. Em meio ao emaranhado de atores e enunciados que constroem o desaparecimento enquanto problema policial, familiar e assistencial, interrogo sobre as possivveis relações entre desaparecimentos e homicídios. Argumento que o ato de fazer desaparecer corpos - enquanto prática-evento - fornece um denominador comum para policiais, milicianos e traficantes, atores que ora colaboram entre si, ora disputam. Corpos e pessoas desaparecidas fazem parte da linguagem do confronto, podendo inclusive ser objeto de transação. O desaparecimento forçado corresponde a um dispositivo de força situado entre a violência estatal e a violência criminal.

Palavras-chave: crime, desaparecimento forçado, familiares de vítimas, violência policial.

Abstract: The article proposes a socio-anthropological analysis about the phenomena of missing people. The reflection is built from the dialogue with the work of other researchers and based on the material prepared in my own fieldwork, which includes the follow up of a collective of families of violence victims, interviews, journalistic documentation, criminal statistics, legislation about the subject and police reports. Amid the tangle of actors and utterances set out to build the disappearance as police,

* Contato: fabio.araujo@ifrj.edu.br

Horizontes Antropológicos, Porto Alegre, ano 22, n. 46, p. 37-64, jul./dez. 2016 http://dx.doi.org/10.1590/S0104-71832016000200002 
family and healthcare problem, the question that emerges is about the possible relationships between disappearance and murders. The argument of this work resides in the fact that the act of making bodies disappear as practice-event provides a common denominator for the police, the militia, and the traffickers, actors who now work together and sometimes compete. Missing bodies and people are part of the confrontational language, and may also be a transaction object. The enforced disappearance corresponds to a power device located between state violence and criminal violence.

Keywords: crime, enforced disappearance, families of victims, police violence.

O desaparecimento de pessoas, dentro da hierarquia das ocorrências policiais, é em si uma ocorrência vista dentro do trabalho policial como sem importância. Associado ao local de moradia e à reputação da pessoa desaparecida, o policial geralmente elabora seu "olhar", constrói suas hipóteses sobre o que poderia ter acontecido em cada situação. Gostaria de iniciar este artigo estabelecendo um diálogo com o trabalho da antropóloga Letícia Ferreira (2011), que realizou uma etnografia numa delegacia especializada em investigar casos de desaparecimento - o Setor de Descoberta de Paradeiros da antiga Delegacia de Homicídios do Rio de Janeiro Centro/Capital. Ao analisar as rotinas burocráticas e os artefatos de gestão por meio dos quais os desaparecimentos são geridos, a autora argumenta que os registros, as investigações e o arquivamento de casos de desaparecimento em delegacias produzem a irrelevância desse tipo de ocorrência. Essa falta de relevância do desaparecimento também aparece denunciada nos relatos dos familiares dos desaparecidos, por mim pesquisados, quando descrevem o tratamento geralmente recebido nas delegacias, quando procuram registrar os casos. ${ }^{1}$

À inferioridade do desaparecimento, aparece associada a inferioridade da favela e de seus moradores. A associação desses elementos faz emergir um artefato do trabalho policial que é a "construção de reputações", afirma Ferreira.

\footnotetext{
Este artigo apresenta parte das reflexões orginalmente desenvolvidas em minha tese de doutorado, defendida em 2012 no Programa de Pós-Graduação em Sociologia e Antropologia do IFCS/UFRJ e, posteriormente publicada como livro (Araújo, 2014). Gostaria de registrar meus agradecimentos aos pareceristas anônimos do artigo, cujos comentários forneceram estimulantes sugestões e caminhos para o desenvolvimento de diversos aspectos deste texto, particularmente a ideia de pensar corpos e pessoas desaparecidas como "objetos de transação" a partir da bibliografia especializada em trocas materiais e imateriais.
}

Horizontes Antropológicos, Porto Alegre, ano 22, n. 46, p. 37-64, jul./dez. 2016 
"Só de olhar" policiais levantam um conjunto de hipóteses para explicar o que pode ter passado a certos desaparecidos. Casos de homens jovens registrados como tendo ocorrido em favelas são agrupados em um leque de hipóteses ainda mais restrito. De modo geral, trabalha-se com as hipóteses de morte, prisão e internação. A nebulosa do tráfico de drogas é acionada para "explicar" o desaparecimento. Desapareceu ou porque usava drogas ou porque era "envolvido com o tráfico". Já em casos protagonizados por mulheres as suspeitas apontam para o envolvimento da pessoa desaparecida com a prostituição ou, simplesmente, porque teria sumido com seu namorado (Ferreira, 2011, p. 148149). A associação entre desaparecimento, favela e criminalidade fornece um pacote interpretativo para especulações sobre os casos de desaparecimento.

A partir do acompanhamento sistemático dos eventos promovidos pela Rede Nacional de Identificação e Localização de Crianças e Adolescentes Desaparecidos (ReDesap), Ferreira relata ainda que havia disputas em torno da administração e gestão dos casos de desaparecimento. Essa rede é uma instância de debates e formulações de propostas para o combate e prevenção ao desaparecimento de pessoas e reúne 47 instituições, entre ONGs e órgãos da administração pública municipal, estadual e federal. Os enredos, dramas e tramas dos casos de desaparecimento são variados. Envolvem desde criança que se perdeu, adolescente que fugiu com a namorada, pessoas que se perderam em decorrência de problemas de saúde mental ou que "sumiram" em razão de catástrofes naturais, até casos de assassinatos com destruição e ocultação de cadáveres. Essa heterogeneidade de casos é organizada, simplificada e domesticada pelos agentes policiais através do recurso a um par de opostos: problema de família versus problema de polícia.

$\mathrm{O}$ entendimento por parte dos policiais era o de que apenas uma pequena parte dos casos de desaparecimento deveriam ser acolhidos como "problema de polícia". Seriam os casos definidos como desaparecimento enigmático aqueles que caberiam à polícia investigar, em oposição aos casos relacionados a "problemas de família", que deveriam ser geridos por órgãos de assistência social: afastamento/abandono do convívio familiar, evasão de custódia legal, subtração por familiares, sequestro, vítimas de calamidades, intempéries e acidentes. Essas são as categorias definidas para serem utilizadas no Cadastro Nacional de Pessoas Desaparecidas. A autora argumenta ainda que, ao definir que a maior parte dos tipos de desaparecimento que ocorrem no Brasil fique a cargo dos órgãos de assistência social, os delegados 
e outros servidores da segurança pública transformaram o Cadastro Nacional de Pessoas Desaparecidas em meio para se desresponsabilizar diante do desaparecimento de pessoas, "institucionalizando um mecanismo de exclusão categórica" (Ferreira, 2011).

Por outro lado, em minhas pesquisas focalizando a experiência de familiares de vítimas de violência, particularmente de casos de desaparecimento forçado, ${ }^{2}$ pude observar uma queixa constante dos familiares em relação ao tratamento de seus casos por parte da polícia. A reputação da vítima, dos familiares e de seus locais de moradia era suficiente para a construção por parte da polícia da (des)importância dessas ocorrências e sua consequente não investigação. Quando as denúncias apontam a participação de policiais ou ex-policiais, seja através da violência policial ou da violência das milícias, em disputa ou em colaboração com o tráfico de drogas, o corporativismo policial torna-se outra barreira à investigação dos casos.

No caso dos "autos de resistência", por exemplo, esta categoria funciona como uma classificação administrativa cujo registro praticamente dispensa a investigação desse conjunto de mortes, sob o pretexto de que não houve ilicitude na produção dessa fração de mortes, porque supostamente seria decorrente de legítima defesa. O artigo 23 do Código Penal Brasileiro trata da “exclusão de ilicitude", nos seguintes termos: "Não há crime quando o agente pratica o fato: I - em estado de necessidade; II - em legítima defesa; III - em estrito cumprimento de dever legal ou no exercício regular de direito."

Diferentes pesquisas e pesquisadores (Barcellos, 2003; Farias, 2014; Misse et al., 2013; Zaccone, 2015), têm apontado para a incompatibilidade entre os fatos narrados por policiais em casos de autos de resistência e os indícios de execução descritos nos exames cadavéricos. ${ }^{3}$ Em outros casos, depoimentos de testemunhas contradizem as versões policiais. Se mesmo quando há o corpo com todos os indícios de execução, como apontam os laudos cadavéricos, e a autoria já está identificada porque o registro de auto de resistência é feito pelo próprio policial autor do homicídio, é difícil investigar e punir

2 Estou usando o termo "desaparecimento forçado" conforme a definição e normatização do direito internacional, que será exposto adiante.

3 Para uma análise da importância do documento laudo cadavérico enquanto plataforma de registro indispensável para a movimentação da engrenagem da gestão governamental dessas mortes, conferir Farias (2014).

Horizontes Antropológicos, Porto Alegre, ano 22, n. 46, p. 37-64, jul./dez. 2016 
os responsáveis, o que dizer dos casos em que o desaparecimento da pessoa oculta um homicídio. Enquanto o auto de resistência, como documento, produz uma legalidade para uma morte praticada por policiais, o desaparecimento produz uma destruição da materialidade do homicídio: a destruição/ocultação do cadáver. A frase-padrão que circula nessa situação é "não tem corpo, não tem crime".

Comparativamente, portanto, enquanto no auto de resistência o questionamento do laudo cadavérico por parte dos familiares de vítimas é central para desfazer a "camuflagem" da violência policial, no caso do desaparecimento forçado a ausência dos corpos e também de documentos, como o atestado de ausência ou atestado de óbito e resultados de exames de DNA para fins de identificação de cadáveres, é um dos obstáculos enfrentados para questionar a ilegibilidade do Estado (Das, 2004). Uma das dimensões fundamentais da produção da legibilidade/ilegibilidade do Estado, nesse caso da gestão das mortes, se realiza na produção dos documentos e das estatísticas criminais através do recurso ao artefato classificatório de auto de resistência e desaparecimento.

As possibilidades de abordagem do fenômeno do desaparecimento de pessoas são tão vastas quanto a pluralidade semântica e as figurações das categorias desaparecimento e desaparecido. As diferentes narrativas e enunciados sobre o assunto dão forma a vários tipos e modalidades de desaparecimento e, além disso, a própria categoria desaparecimento é fugidia, de difícil definição, exatamente pela grande variedade de situações que engloba. A discussão sobre o desaparecimento pode levar à reflexão de vários temas, e cada perspectiva analítica pode considerar problemas diferentes, assim como são variados os circuitos e as trajetórias que se podem percorrer para pesquisar esse assunto. Neste artigo, meu objetivo é problematizar as relações entre desaparecimentos e homicídios. A questão que desejo levantar e considerar analiticamente é: o desaparecimento de pessoas corresponde, em alguma medida, a um fenômeno/conceito de práticas particulares que aparecem agrupadas na generalização da representação social da violência? A violência urbana enquanto núcleo de significação reúne em um mesmo "pacote" fenômenos e conceitos díspares. Que nexos podem existir e articular as categorias desaparecimento/desaparecido a práticas de extermínio?

Em minha trajetória de pesquisa o tema apareceu a partir de meu interesse em estudar a experiência de familiares de vítimas de violência policial. Durante meu trabalho de campo acompanhando familiares identifiquei, 
partindo de um estudo de caso particular, vários outros que começaram a aparecer e constituir uma coleção de casos, caracterizados pela ausência dos corpos das vítimas. A figura do desaparecido começou a se consubstanciar de uma certa maneira nos relatos dos familiares. Esses relatos permitiram descrever algumas técnicas de fazer desaparecer, desvelar algumas dinâmicas, identificar alguns atores e situações. Além disso, a circulação de casos de desaparecimento envolvendo as dinâmicas da violência estatal e criminal nos meios de comunicação forneceram outro horizonte de publicização (Cefaï, 2002). Os registros de ocorrência policial são documentos oficiais que também fornecem indícios para subsidiar uma problematização das relações entre desaparecimento e homicídio.

Com base nesses diferentes materiais, produzidos a partir de uma perspectiva de inspiração etnográfica, e no diálogo com o trabalho de outros pesquisadores, um conjunto de questões vem se delineando ao longo de minha pesquisa. Como tem sido construído o desaparecimento enquanto problema social e sociológico? Dentro dessa problemática maior dos desaparecimentos, que lugar ocupa o desaparecimento forçado? $\mathrm{O}$ que se passa nos casos em que os indícios e as denúncias apontam para um homicídio por trás do registro de desaparecimento? Quem são os envolvidos nesses casos? O que diz o Estado e o que contam os familiares dos desaparecidos? Onde estão os corpos ou o que se ouve dizer sobre eles? Que fim teriam levado?

É preciso, no entanto, chamar a atenção, desde já, para os limites do enquadramento e da generalização, da abordagem, do material analisado e do trabalho de campo, e, consequentemente do alcance das afirmações e das análises contidas no escopo deste artigo. Uma primeira observação a ser feita, nesse sentido, é sobre a impossibilidade de identificar estatisticamente a proporção de casos de desaparecimento forçados ${ }^{4}$ no universo geral dos casos de desaparecimento. Esta não é minha preocupação aqui. Desaparecimento forçado é uma categoria que aparece nas convenções do direito internacional, porém, a polícia não opera com essa categoria. $\mathrm{O}$ termo adotado pela polícia do Rio de Janeiro é "pessoa desaparecida". Trata-se de um registro administrativo, considerado "provisório" até que o caso possa ser reclassificado no

4 Logo adiante apresentarei a definição de desaparecimento forçado, segundo as normatizações internacionais. 
quadro das ocorrências policiais. Essa forma de registro engloba uma variedade de tipos e circunstâncias de desaparecimento, desde uma pessoa que saiu de casa e se perdeu por problemas psiquiátricos, abandono de incapaz, fuga do lar, tráfico de pessoas (entre outros), até os casos que podem ser classificados como desaparecimento forçado conforme as normativas internacionais.

Outro obstáculo é a ausência de dados mais qualificados sobre o fenômeno dos desaparecimentos. Quando esses dados existem, ainda que parcial e fragmentariamente, há a dificuldade de acesso a eles. É comum pesquisadores esbarrarem na negativa do Estado em disponibilizar os dados. O segredo de Estado configura-se como uma margem para a produção de suas regras e de sua ação prática, na medida em que elas são em alguma medida desconhecidas e incertas, ou quando se encontram definidas na letra da lei, mas é na imprevisibilidade e contingência da ação de seus agentes que ela se faz, se materializa. Ao Estado em sua dimensão totalizante, abstrata, se contrapõem as experiências particulares e concretas de cada pessoa ou grupo que transita e relaciona-se com os diferentes segmentos do Estado (Abrams, 2006; Vianna, 2013).

As antropólogas Das e Poole (2004), em sua proposta de realizar uma antropologia das margens do Estado, desde uma perspectiva etnográfica, argumentam que as práticas documentárias e a produção de estatísticas do Estado objetivam em alguma medida o controle sobre sujeitos e territórios. Elas criticam a noção que compreende o Estado em função de sua legibilidade. Ao contrário, os diferentes trabalhos publicados no livro sugerem que os vários espaços, formas e práticas diferentes pelas quais o Estado é vivido e desfeito através da ilegibilidade de suas próprias práticas, documentos e palavras, é o que o define ou o constrói.

A ilegibilidade do Estado é apresentada, compreendida e interpretada como a dificuldade de leitura e compreensão de suas regras e regulações. É essa questão da ilegibilidade do Estado que se coloca no caso do desaparecimento. A dificuldade de acessos às práticas documentárias, às estatísticas e aos documentos oficiais do Estado no caso dos desaparecimentos no Rio de Janeiro cria uma atmosfera de ilegibilidade de algumas práticas estatais e alguns fenômenos objetos de ação estatal. É o Estado produzindo sua ilegibilidade, ora através da forma como interpreta, classifica fenômenos e dados e faz circular explicações, ora através do recurso ao segredo, evitando a liberação e publicização dos dados. 
No caso do extermínio decorrente da ação estatal, direta e indireta, o governo dessas mortes apresenta-se como um "espaço governável" marcado pelas tensões e disputas em torno das práticas estatais e suas tecnologias de governo. Leis, laudos periciais, boletins de ocorrência, depoimentos, testemunhas, moralidades, apropriação privada do Estado via mercadoria política, ${ }^{5}$ ocultação de cadáver: tudo isso compõe a cena que configura as fronteiras do legal, ilegal, informal e ilícito, que abarca um grande leque de fenômenos e situações (Telles; Hirata, 2007).

Já afirmei anteriormente, apoiado no trabalho de Ferreira (2011), que o fenômeno do desaparecimento de pessoas é atravessado por disputas entre os diferentes atores envolvidos nessa problemática. São esses embates que ajudam a definir o desaparecimento de pessoas como uma causa, um problema social, assistencial e policial. Entretanto, uma problematização do tipo penal internacional de desaparecimento forçado geralmente tende a ficar completamente fora desse cenário de debates e das figurações do desaparecimento. É sob esse ângulo do desaparecimento forçado que desejo fazer circular, no espaço deste artigo, uma reflexão socioantropológica sobre o ato de fazer desaparecer corpos.

\section{A prática do desaparecimento forçado e as normatizações internacionais}

Dentro da diversidade de atores e enunciados que constroem o desaparecimento enquanto um problema, opto por utilizar o termo "desaparecimento forçado" para me referir às situações de desaparecimento que focalizarei. Meu interesse de pesquisa e minha perspectiva analítica têm o objetivo de tematizar a violência estatal, especialmente a violência policial e suas dinâmicas situacionais em torno do mundo do crime. Nesse sentido, o conceito de desaparecimento forçado, tal como definido nas normatizações do direito internacional, qualifica com maior precisão o quadro de situações particulares que analiso. Meu argumento é o de que o desaparecimento forçado é uma faceta concreta

\footnotetext{
5 O conceito elaborado por Misse (1999, p. 299-300) define "mercadoria política" como "toda mercadoria cuja produção ou reprodução depende fundamentalmente da combinação de custos e recursos políticos, para produzir um valor de troca político ou econômico. O emprego de uso da força (ou a sua ameaça) para a realização de fins econômicos privados é a sua modalidade historicamente mais abrangente.”
}

Horizontes Antropológicos, Porto Alegre, ano 22, n. 46, p. 37-64, jul./dez. 2016 
dentre os diferentes fenômenos e conceitos que geralmente aparecem agrupados indistintamente na categoria "violência urbana"6 (Feltran, 2014).

Uma das imagens mais marcantes vinculadas ao quadro de violações de direitos humanos na história recente da América Latina foi a emergência da figura do desaparecido político. ${ }^{7}$ Durante os regimes militares latino-americanos o desaparecimento forçado tornou-se instrumento de repressão e dominação política da ditadura. Quando os militares latino-americanos começaram a utilizar a prática de desaparecimento forçado de pessoas como política de Estado, acreditavam ter encontrado a chave para um crime perfeito: dentro da sua lógica inumana, não havendo vítimas, não haveria perseguidos e, portanto, também não haveria crime (Molina Theissen, 1998).

O desaparecimento forçado se inicia com a captura violenta e arbitrária da pessoa, que em seguida é levada para lugares desconhecidos. Na maioria dos casos, é torturada e assassinada, sem que se deixem vestígios ou rastros do corpo, nem dos lugares onde esteve detida, nem de quem perpetrou o crime. Em muitos casos os corpos são mutilados para dificultar sua identificação ou as características da morte. As pessoas podem ser levadas a prisões clandestinas onde podem ser objeto de agressões físicas. E ainda, com o objetivo de se desfazerem do cadáver, os responsáveis podem enterrar os corpos em cemitérios clandestinos ou jogá-los em rios (Calveiro, 2013; Molina Theissen, 1998).

6 Como afirma Feltran (2014, p. 301): “A representação da 'violência urbana' constitui-se fundamentalmente, em minha interpretação, num processo de associação arbitrária entre conceitos e fenômenos distintos, ao longo do tempo, que comporiam um único dispositivo, que ao reificar - por mecanismos diversos - se torna 'realidade'. Nela, estão naturalmente conectados fenômenos e conceitos tão díspares quanto criminalidade, drogas ilegais, mercados ilícitos, armas de fogo, facções, quadrilhas, corpos pardos e pretos, territórios urbanos e pobreza. Se o rigor analítico remete que cada um desses conceitos seja tratado considerando-se as distinções evidentes que carregam, nessa representação, ao contrário, eles são umbilicalmente associados. Cada um e a totalidade deles poderiam, além do mais, significar uma faceta do nexo mais amplo, quando não tomado simplesmente como um sinônimo da 'violência urbana'. [...]. A imprecisão conceitual que situa a "violência' no centro da significação dos pobres urbanos, seus territórios e modos de vida é, politicamente, precisa.”

7 Em oposição ao desaparecido político/forçado, Oliveira (2012, p. 11) propõe a noção de desaparecido civil, caracterizado como "uma pessoa que saiu de um ambiente de convivência familiar, ou de algum grupo de referência emocional-afetiva - como uma roda de amigos -, para realizar qualquer atividade cotidiana, não anunciou a sua intenção de partir daquele lugar e jamais retornou. Sem motivo aparente, sumiu sem deixar vestígios. Nesse caso, colocam-se ao menos três problemas imediatos: 'saber o que ocorreu', 'saber o que fazer', 'saber a quem procurar'.,

Horizontes Antropológicos, Porto Alegre, ano 22, n. 46, p. 37-64, jul./dez. 2016 
No Brasil, no estado de São Paulo, no dia 4 de setembro de 1990, foi localizada a vala clandestina de Perus, ${ }^{8}$ com 1049 ossadas, que se encontravam dentro de sacos plásticos, todos sem qualquer identificação. Nesse cemitério clandestino foram enterrados corpos de indigentes mortos por esquadrões da morte e presos políticos assassinados pela violência do regime militar. Milhares de presos políticos foram enterrados em diversos desses cemitérios e valas clandestinas pelo Brasil afora, e na maioria dos casos, como informa o relatório final da Comissão Nacional da Verdade (2014), não se tem notícias de seu paradeiro.

Diante dessa prática do Estado de lançar mão de um poder desaparecedor, conforme a expressão da cientista política argentina Pilar Calveiro (2013), a comunidade internacional foi instada a buscar meios para coibir a prática do desaparecimento forçado. Uma série de tratados e normatizações internacionais foram elaborados e pactuados para enfrentar o problema, entre eles: a Declaração sobre a Proteção de Todas as Pessoas contra os Desaparecimentos Forçados, da ONU (United Nations, 1992); a Convenção Interamericana sobre o Desaparecimento Forçado de Pessoas, aprovada pela Organização dos Estados Americanos (1994); o Estatuto de Roma, que estabeleceu a criação do Tribunal Penal Internacional em 1998 (International Criminal Court, 2011). Em 4 de dezembro de 1995 o Congresso Nacional brasileiro decretou e o presidente Fernando Henrique Cardoso sancionou a Lei dos Desaparecidos (Brasil, 1995).

A Corte Interamericana de Direitos Humanos, no caso Gomes Lund e outros (Guerrilha do Araguaia), em sentença de 24 de novembro de 2010, responsabilizou o Brasil a tipificar o crime de desaparecimento forçado de pessoas. Atualmente tramita no Congresso Nacional o projeto de lei $n^{\circ} 6240 / 2013$, que visa acrescentar o artigo 149-A ao Código Penal Brasileiro, para tipificar o crime de desaparecimento forçado. Estima-se que no Brasil anualmente desaparecem entre 40.000 e 50.000 pessoas. No Rio de Janeiro, são registrados por ano entre 4000 e 5000 casos. Quantos serão desaparecimentos forçados? Quantos desaparecimentos forçados não são sequer registrados?

8 Sobre a vala de Perus, conferir o relatório da CPI Perus - Desaparecidos Políticos (Câmara Municipal de São Paulo, 1992). 


\section{A relacão entre desaparecimentos e homicídios: as disputas em torno dos dados}

O desaparecimento forçado ficou, no Brasil, associado aos desaparecidos políticos. Porém, se tomarmos as definições expressas nas normatizações internacionais, notamos que a prática do desaparecimento forçado não terminou com o fim da última ditadura civil-militar no Brasil. O ato de fazer desaparecer pessoas persiste na sociedade brasileira pós-ditadura. Se durante os regimes militares o desaparecimento forçado foi uma política de Estado para fins de repressão política, atualmente ele tornou-se uma prática da linguagem da violência urbana. A região metropolitana do Rio de Janeiro permanece repleta de cemitérios clandestinos. Uma mãe cujo filho estava desaparecido, disse-me certa vez que, "caso se queira pesquisar os casos de desaparecimento, pode-se começar drenando todos os rios da cidade".

A violência policial, a ação de milícias e os conflitos armados envolvendo facções que atuam no comércio de drogas ilícitas territorializado nas "bocas" têm gerado um alto número de mortes, principalmente de jovens, do sexo masculino, negros e moradores de favelas e bairros pobres. Parte dessas mortes, produzidas pela violência policial, têm sido classificadas como autos de resistência (Farias, 2014; Zaccone, 2015). Além disso, uma hipótese a ser problematizada é se uma fração de homicídios, praticada com a participação de agentes estatais, vem sendo ocultada através do recurso ao desaparecimento. Não dispomos de dados suficientes, porque eles não são disponibilizados pelo poder público, para estabelecer uma relação entre números de autos de resistência e de desaparecimentos forçados. No entanto, há indícios de que isso ocorre repetidamente, como registros de ocorrência, relatos de familiares, reportagens jornalísticas, informações registradas através das linhas telefônicas do Disque-Denúncia, depoimentos de autoridades públicas.

No Rio de Janeiro, uma das polêmicas e controvérsias envolvendo a questão dos desaparecimentos e suas possíveis conexões com práticas de extermínio, incluindo a violência policial e a criminal, ganhou espaço com alguns episódios ocorridos durante o governo Sérgio Cabral. O governador foi duramente criticado por alguns segmentos da sociedade por desenvolver e praticar uma política de segurança pública baseada no confronto, cujo resultado foi um alto índice de mortes. Nesse contexto, um dos fatos que marcaram a conjuntura do ano de 2008 foi a exoneração da antropóloga Ana Paula 
Miranda da presidência do Instituto de Segurança Pública (ISP), órgão vinculado à Secretaria de Segurança Pública, responsável pela sistematização das estatísticas criminais. As estatísticas criminais, como afirmam Lima e Borges (2014, p. 214), "ao contrário de revelarem os fatores criminógenos e identificarem situações sociais que favoreçam a ocorrência de crimes, falam do crime e do criminoso como construções sociais". A existência de séries históricas de estatísticas criminais tem o objetivo de auxiliar no desenho e implementação de políticas públicas mais eficientes, mas elas não falam por si. Os dados não falam por si, as categorias e classificações são socialmente construídas conforme os contextos. A produção das estatísticas criminais não deixa de ser, portanto, um campo de disputa em torno de categorias e classificações.

São essas disputas que pareciam estar em jogo na exoneração da antropóloga Ana Paula Miranda do ISP. A antropóloga foi exonerada em fevereiro de 2008, após divulgar um número recorde de mortos pela polícia. Segundo a antropóloga, após sua saída houve um redirecionamento do ISP para o desmonte e o mais grave seria a perda de legitimidade dos dados sobre criminalidade. Afirmou que "o governo não contabiliza os autos de resistência na soma final de homicídios dolosos". E complementou dizendo que "alguns casos que são claramente homicídios, como os corpos carbonizados encontrados, estão sendo registrados como encontro de cadáveres e ossadas". Segundo ela, os registros de autos de resistência, desaparecimento, encontro de ossadas e cadáveres continuam em tendência crescente desde 2000. A estratégia do governo estadual para reduzir as taxas de homicídios teria sido redistribuí-los nessas outras categorias, os números estariam sendo camuflados porque não agradavam às autoridades. O secretário de Segurança Pública, José Mariano Beltrame, afirmou, por sua vez, que a postura de Ana Paula Miranda era muito acadêmica e a ele interessaria um perfil mais técnico.

A demissão de Ana Paula ocorreu em fevereiro de 2008, mas os questionamentos da política de segurança pública do governador Sérgio Cabral já vinham ocorrendo há tempos. O número crescente de casos de desaparecimento também passou a ser alvo de dúvidas, críticas e contestações. A ONG Rio de Paz chegou a organizar, no dia 9 de dezembro de 2008, um protesto na orla de Copacabana. Manequins envolvidos em pneus representavam corpos de pessoas enterradas em valas comuns e cemitérios clandestinos, fazendo referência a uma forma de matar praticada por traficantes e conhecida como "micro-ondas". 
Outro elemento de conjuntura para se pensar os desaparecimentos tem a ver com a atuação das milícias. As milícias merecem aqui um ponto de destaque. Não há uma definição consensual sobre o que seja a milícia. Algumas de suas características, segundo Cano e Duarte (2012), seriam: 1) o controle de um território e da população que nele habita por um grupo armado irregular; 2) o caráter coercitivo desse controle; 3) o lucro particular como motivação central; 4) um discurso de legitimação fundamentado na proteção dos moradores na instauração da ordem; 5) participação ativa e reconhecida dos agentes do Estado. Algumas pesquisas sobre milícias, como a realizada por Cano e Duarte (2012) e intitulada "No sapatinho": a evolução das milícias no Rio de Janeiro (2008-2011), têm sugerido a hipótese de que o desaparecimento possa ser uma alternativa adotada pelas milícias como forma de evitar expor seus crimes. Autoridades entrevistadas pelo pesquisador afirmaram que as milícias foram mudando seu proceder com tempo, "cessando de matar publicamente e passando a sumir com os corpos".

É impossível definir com precisão e até mesmo em termos estimativos a magnitude do fenômeno do desaparecimento forçado hoje. Uma série de obstáculos se apresenta. Um deles é que o desaparecimento forçado não é atualmente tipificado como crime no Brasil. Isso significa que não existe registro oficial dessa modalidade de desaparecimento. O que se tem no Brasil hoje, guardadas as diferenças de um estado para outro, é um registro administrativo de "pessoa desaparecida".

Outro obstáculo é a negativa por parte do Estado em disponibilizar os dados para pesquisadores, dificultando um entendimento ampliado e mais preciso do fenômeno. O mesmo Estado que nega informação ou investigação sobre os casos de desaparecimento também se nega muitas vezes a disponibilizar os dados para que a sociedade possa conhecer o fenômeno e pensar políticas públicas de enfrentamento do problema, em que pese a existência da Lei de Transparência Pública que objetiva garantir o direito à informação. Após a repercussão do caso Amarildo, ${ }^{9}$ a necessidade e a demanda por conhecer a realidade dos desaparecimentos e seus possíveis nexos com a violência policial mobilizou um grupo de entidades de direitos humanos e pesquisadores em torno de uma pesquisa acerca dessa temática. O primeiro passo foi solicitar

9 O caso Amarildo será apresentando na seção seguinte. 
à Secretaria de Segurança Pública, com base na Lei da Transparência Pública, a disponibilização dos registros de ocorrência de desaparecimentos. A solicitação dos pesquisadores, entretanto, foi negada e a pesquisa não foi adiante.

Se, por um lado, há o difícil acesso aos dados oficiais, por outro, os familiares que deambulam atrás de informações e sofrem a insuportabilidade da perda são protagonistas fundamentais na consubstanciação da categoria "desaparecimento forçado". São eles que, ao testemunhar, relatar, contar, falar, narrar, agir, em nome do "caso", ensaiam uma tomada de voz que dê forma à personagem fantasmagórica do desaparecido forçado. Enquanto na rotina do trabalho policial o desaparecimento é produzido como uma ocorrência irrelevante, nos relatos dos familiares dos desaparecidos que acompanhei ${ }^{10} \mathrm{o}$ problema é construído como algo que demanda urgência de ação. A seguir, apresento algumas histórias e situações, narradas pelas mães dos desaparecidos, e que fornecem algumas pistas para uma análise situacional do fenômeno. Os nomes foram alterados para preservar o anonimato das pessoas, menos no caso Amarildo, que se tornou um caso com repercussão pública e midiática.

\section{0 caso Amarildo e outros: rumores, relatos e indícios}

Entre os dias 13 e 14 de julho de 2013, uma operação policial realizada na Rocinha, batizada de Paz Armada, mobilizou 300 policiais para prender suspeitos de um arrastão ocorrido nas proximidades da favela. Trinta pessoas foram presas, entre elas o ajudante de pedreiro Amarildo Dias de Souza. Ele foi conduzido à Unidade de Polícia Pacificadora (UPP) da Rocinha e desde então não há notícias de seu paradeiro. O caso foi marcado por disputas internas na polícia civil. Inicialmente as investigações de um delegado atribuíam a responsabilidade pelo "sumiço" de Amarildo a traficantes da Rocinha e buscaram construir a reputação da vítima como traficante, enquanto outra linha de investigação, conduzida por outro delegado, defendia que Amarildo não era traficante e havia policiais envolvidos no desaparecimento. A conclusão da polícia civil foi que Amarildo foi torturado e morto, porém seu corpo nunca apareceu. Vinte e cinco policiais da UPP foram acusados de participação no

${ }^{10} \mathrm{O}$ trabalho de campo que, em uma de suas dimensões, consistiu no acompanhamento dos familiares foi realizado entre julho de 2009 a agosto de 2011. Nesse período, além de acompanhar as mobilizações políticas em torno de seus casos, realizei entrevistas com 35 familiares de pessoas desaparecidas.

Horizontes Antropológicos, Porto Alegre, ano 22, n. 46, p. 37-64, jul./dez. 2016 
crime, além de policiais do Batalhão de Operações Especiais (Bope). O caso tornou-se símbolo dos desaparecimentos forçados praticados pela polícia e geralmente não investigados. Dessa vez, entretanto, o caso foi abraçado pelas manifestações de junho de 2013, que tomaram as ruas do país, e ganhou repercussão internacional através dos meios de comunicação. Esse é um caso emblemático, porém não é único.

\section{Policiais, milicianos, traficantes e corpos degolados}

Outro caso é o de Maria do Retiro, que tem aproximadamente 40 anos. É moradora de uma área popular na Zona Norte do Rio de Janeiro. Alguns moradores referem-se ao lugar como favela, outros como bairro. Conheci Maria do Retiro através da mediação de outra mãe que eu havia entrevistado. Eram vizinhas e tinham histórias parecidas. Os filhos de ambas foram mortos, segundo elas, por milicianos. Após um tempo de desaparecimento, as duas encontram partes dos corpos dos filhos. Uma encontrou o corpo sem a cabeça, a outra encontrou a cabeça sem o resto do corpo.

Maria do Retiro tinha cinco filhos e dois netos. Um dos filhos foi "vitimado na comunidade", como ela diz. Entre 15 e 17 anos esse filho "foi envolvido com o tráfico". Ao falar sobre o caso, Maria do Retiro enfatiza que o filho "mudou de vida" e lamenta que "ele não estava trabalhando de carteira assinada porque não teve oportunidade", mas trabalhava. Era o responsável pela marcação dos jogos de futebol em uma quadra administrada pelo Viva Rio.

Em 2007, a milícia entrou na localidade e passou a controlar a área. Já havia quase quatro anos que seu filho se encontrava afastado do tráfico. Segundo Maria, ele estava "com a consciência limpa". Muitas pessoas orientaram seu filho a ir embora da "comunidade", porque temiam que algo pudesse lhe acontecer. Confiante de que nada lhe aconteceria, o filho (acompanhado da mãe) procurou os milicianos da área que são policiais, ex-policiais e bombeiros, para explicar sua situação.

Pergunta: Ele procurou esses policiais para conversar com eles?

Maria do Retiro: É. Lá na praça mesmo. Eu fui com ele. Chegando lá, ele explicou que não tinha mais nada a ver. Que estava trabalhando. Que ele queria criar o filho dele, que na época estava com três anos de idade. Ia completar três anos. Aí, eles falaram: "Se você quiser ficar assim, está legal, você pode continuar 
aqui. E se não tiver envolvimento com ninguém, está tudo bem.” E os policiais ficaram um período lá na comunidade. Aí houve um assassinato de dois jovens militares em um baile funk lá dentro mesmo da comunidade. Lá, o pessoal falou que foi um dos filhos desse policial, junto com uns outros que mataram os dois rapazes. Quer dizer, o delegado esteve lá, teve uma repercussão danada. Passou na televisão. Então os policiais se afastaram da comunidade. Ficou quem? Os agregados deles lá, os rapazes que eram da facção criminal da $\mathrm{ADA},{ }^{11}$ que eram inimigos da facção que meu filho frequentou.

Pergunta: Qual era facção?

Maria do Retiro: É o Terceiro Comando. E eles continuaram lá, sozinhos. Então, a partir do momento que esses policiais saíram da comunidade, começou a matança em série. Eles matando, matando, matando. Aí, eu tenho uma filha que até hoje está em situação de rua, porque é viciada em crack. Já era antes de matarem meu filho. E ela, em uma ocasião, levou um tiro de bala perdida. E ela ficou usando uma bolsa de colonoscopia. Então, ela teve que ficar internada para fazer a reversão. E justamente eu estava no hospital com ela, para ver ela ser operada. $\mathrm{Eu}$ fui em casa tomar banho, trocar de roupa. E ele chegou com uma sapateira que eu estava precisando lá em casa. E ele: "Mãe, eu peguei essa sapateira com um rapaz, a prestação, para a senhora." Aí me deu a sapateira, estava com biscoito, com uma latinha de Coca-Cola, me ofereceu. Aí, foi a última vez que eu o vi. Aí, eu falei para ele: "Vou voltar para o hospital, que a Kelly já foi operada." Aí tomei banho, comi uma coisinha lá e voltei para o hospital. Aí, eu cheguei no hospital e de madrugada teve um tiroteio lá. Teve uns tiros lá que me deixaram nervosa. Quando foi uma e pouca da manhã eu não conseguia dormir, com um coração inquieto. Sabe!? Uma respiração ofegante, um negócio. E eu querendo sair de lá. Aí, de manhã, meu irmão e minha irmã foram lá me buscar, dizendo que tinha acontecido um problema com ele. Eu já esperava, sabe. Eu perguntei: “Aconteceu alguma coisa?" Eles falaram: "Aconteceu um problema com o Válter. Eles sumiram com o corpo dele. Ele foi degolado.” Minha irmã disse que foi lá para pedir para eles dizerem onde estava o corpo, para fazer o enterro. Aí eles falaram que não. Todas as pessoas que eles mataram. Eles disseram: "Não tem corpo, não tem corpo."

Pelo relato de Maria do Retiro, os milicianos atuavam em parceria com traficantes. E os traficantes que estavam dominando a área nessa época eram de facção rival àquela a que havia pertencido o filho de Maria do Retiro. Essa

11 ADA é a sigla da facção criminosa Amigos dos Amigos, que atua no comércio varejista de drogas no Rio de Janeiro.

Horizontes Antropológicos, Porto Alegre, ano 22, n. 46, p. 37-64, jul./dez. 2016 
história difere-se das versões que muitas vezes circulam sobre as milícias no Rio de Janeiro, segundo as quais a milícia entra no território para expulsar os traficantes e gerir o funcionamento de vários mercados ilícitos. O que se nota nessa história são "ligações perigosas" entre policiais, milicianos e traficantes locais de droga, cada um querendo sua parte na "gestão" 12 dos mercados ilegais. E cada um recorrendo às "mercadorias políticas" (Misse, 1999) acessíveis para garantir seu poder local.

\section{Um filho desaparecido e uma ossada no portão}

Maria das Dores mora na Zona Oeste do Rio de Janeiro, na região de Campo Grande. Conta que o filho saiu para trabalhar e não voltou mais. Tomada pelo nervosismo, já pensava na cobrança que faria ao filho quando o encontrasse. Segundo ela, diria ao filho que não admitia que ele dormisse fora de casa sem que comunicasse. Mas o filho não voltara e começaram as buscas. A primeira atitude foi procurar saber entre os amigos do filho "quem era a namorada que ele havia arrumado". Após a descoberta, o passo seguinte foi falar com a namorada, que disse que a última vez que havia visto Wesley fora em um churrasco, no domingo anterior. Depois disso não foi possível encontrá-lo novamente porque ela estava trabalhando. Diante dessa informação da namorada, Maria das Dores começou a ficar agitada e procurou uma delegacia de polícia. Na delegacia, os policiais pediram que ela fosse primeiro ao local de trabalho do filho para averiguar se conseguia alguma informação. No local de trabalho, os funcionários da empresa disseram que na quarta-feira ele não retornou para trabalhar.

Maria das Dores voltou então à delegacia para fazer o registro de ocorrência e aproveitou para deixar fotos do filho com os policiais. Na delegacia, os policiais perguntaram sobre as últimas pessoas que haviam tido contato com Wesley. Ela passou esses nomes aos policiais, que investigaram e descobriram que essas pessoas alegaram que o estavam procurando para saírem para comer

12 "Gestão" é uma palavra que aparece na própria fala de Maria do Retiro. "No início da gestão dessa milícia lá, algumas pessoas que eles mataram, o pessoal estava dizendo que eles levavam a pessoa lá para a Baixada Fluminense, que tinha um sítio que tinha um jacaré. O pessoal falava. Então, eles matavam a pessoa ou jogavam a pessoa viva." 
pizza. Maria das Dores conta que estranhou essa informação, porque o filho não tinha o hábito de sair de casa, a não ser para trabalhar. E quando retornava do trabalho, o único lugar para onde costumava ir era uma terra que ele tinha, onde gostava de criar animais. Fora esse trajeto, o filho não tinha o hábito de sair para outros lugares. Conta que estranhou que por dias seguidos apareceu uma pessoa em sua casa procurando por seu filho, segundo ela, pessoa conhecida, colega dele. No dia do "sumiço" do filho, a mesma pessoa apareceu novamente perguntando se Wesley havia chegado.

E o desespero de Maria das Dores só aumentava. Começou a recorrer a todas as pessoas que estivessem ao seu alcance para pedir ajuda. Pastora de uma igreja evangélica, disse que primeiramente buscou força em Deus e em si mesma, depois foi atrás de amigos, vizinhos, "o povo da Igreja". Chegaram a realizar várias manifestações fechando a Avenida Brasil, carreatas dentro e fora do bairro, espalhou cartazes. Chegou a ir até a Rede Record procurar por Wagner Montes, que apresenta um programa policial nesse canal de televisão. $\mathrm{O}$ apresentador chegou a enviar uma equipe de reportagem à sua casa:

Mandou a reportagem até aqui. Eles entraram aqui dentro, fizeram a reportagem, tudo direitinho aqui comigo. Aí no meio disso tudo ainda teve um outro problema, porque depois a Record pegou meu número e passou para um outro repórter do Extra, que entrou dentro da minha casa, me pediu para dizer tudo que tinha acontecido. Eu disse, abri meu coração pra eles. Pegaram a reportagem, montaram uma reportagem e acusaram meu filho de miliciano, estuprador e que tinha poucos dias que ele estava fora da cadeia. Então naquela hora, além do meu filho estar desaparecido, ainda agora querem manchar a moral do meu filho.

Nota-se nesse relato que a relação dos familiares com a imprensa passa por um dilema: por um lado, há a necessidade de dar visibilidade ao caso na mídia, por outro, a incerteza sobre o que e como será publicado. A circulação do caso na mídia pode tanto ajudar como pode igualmente atrapalhar e gerar decepções. A atuação do jornalista e a política editorial do jornal podem ser traduzidas em um engajamento ao sofrimento do outro, mas pode também significar uma espetacularização desse sofrimento e um obstáculo a mais para os familiares. Nesse caso particular, Maria das Dores conseguiu que o jornal fizesse uma retratação pública, limpando moralmente o nome do filho. Ela diz que foi até uma delegacia, conversou com "alguns coordenadores" e eles pediram ao jornal que fosse feita a retratação. 
Maria continuou as buscas percorrendo lixeiras, lugares de desova, hospitais, valões de esgoto, rios. Onde quer que aparecesse uma denúncia indicando onde o filho poderia estar, lá estava essa mãe atrás dele. Até que, quatro meses após o desaparecimento, mais uma situação desoladora aconteceu. Maria das Dores relata que estava dormindo, quando, por volta de duas e meia, três horas da madrugada, bateram forte em seu portão e ela acordou assustada. Como é pastora de uma igreja evangélica e as pessoas tinham o hábito de procurá-la para pedir orações, pensou que pudesse ser alguém precisando de ajuda. Correu e abriu o portão. Levou um susto ao se deparar com uma ossada espalhada em seu portão. Deu um grito e fechou o portão, voltou para dentro de casa assustada e não sabia o que fazer, até que começou a ligar para os vizinhos que moram perto e pediu para que estes olhassem de suas janelas para seu portão, para ver o que estava acontecendo em frente à sua casa. Os vizinhos olharam e disseram que havia uma ossada em seu portão, mas que não havia nenhuma pessoa por perto.

Maria das Dores interrompe a entrevista por um instante, para pedir ao filho que buscasse umas fotos para nos mostrar. Eram as fotos da ossada colocada em sua porta. Disse que bateu umas fotos, começou a ligar para a polícia e ninguém atendia o telefone. Também buscou ajuda ligando para alguns amigos policiais. Estes conseguiram, finalmente, ligar e falar na delegacia, e pediram que fosse enviada uma viatura da polícia ao local. Quando a viatura chegou, duas horas depois, o estado emocional de todos da casa já estava muito abalado. $\mathrm{O}$ filho estava desaparecido e agora havia uma ossada diante o portão de casa.

Eu peguei tudo com a mão, coloquei num saco, botei do lado, até a polícia chegar. Duas horas depois eles chegaram. Aí falaram pra mim que eu não poderia ter colocado a mão. Eu falei para o policial: "Eu não vou deixar ninguém fazer chacota, nem mexer com o emocional da minha família nisso tudo, né!" E tinha um bilhete onde estava escrito: "Fulano já foi, caiu o Beltrano." Era um moço, um jornaleiro que tinha aqui que mataram. E disse assim: "Caiu o Beltrano e quem tentar se levantar contra mim, vai ter o mesmo fim." Aí dizia assim: "Sicrano não manda mais, quem manda agora sou eu", alguma coisa assim. Aí eu peguei o bilhete, segurei e entreguei pra polícia. Quando deu mais ou menos quase 12 horas, a polícia, a perícia veio, tiraram as fotos. Naquele dia eles pediram pra eu ir até a Delegacia de Homicídios. Eu falei que eu não tinha nem condições, porque eu precisava contar à mãe da minha neta o que tinha acontecido, ela não sabia. Aí, quando chegou de noite, chegaram três homens aqui, dizendo 
ser da $\mathrm{P} 2 .{ }^{13}$ Se identificaram rapidamente, nem me lembro o nome deles. E no outro dia eu parti para a delegacia e dei meu depoimento do que tinha acontecido. E falei que essas pessoas tinham aparecido na minha casa, eles falaram que não sabiam informar que a P2 tivesse ordem para vir aqui.

Segundo Maria das Dores, essas pessoas que foram até sua casa e se identificaram como policiais da P2 disseram que ficaram sabendo do ocorrido e queriam saber se alguém tinha visto quem colocou as ossadas em seu portão. Ela disse aos supostos policiais que não tinha visto nada e não possuía qualquer informação sobre quem teria colocado as ossadas em seu portão. Eles, por sua vez, disseram que em poucos dias seria requerido que ela e o esposo fossem ao Instituto Médico Legal para fazer o exame de DNA. Após grande dificuldade para fazer o DNA, comprovou-se que realmente a ossada era de seu filho. O passo seguinte foi providenciar o atestado de óbito. Quando finalmente conseguiu, ao chegar no Instituto Médico Legal foi informada que os restos mortais de seu filho haviam sido enterrados como indigente. $\mathrm{O}$ passo seguinte foi correr ao cemitério para identificar a sepultura do filho. Era o dia de aniversário do filho e o dia em que se completava um ano que ele havia sido morto.

A única coisa que as pessoas comentam no meu bairro foi essa. Que a ossada foi colocada no meu portão, porque alguém pediu, alguém implorou para que as pessoas que fizeram isso devolvessem alguma coisa. Porque já não aguentavam mais ver meu sofrimento. Não aguentavam me ver ficar pra lá, pra cá, procurando um fantasma. Um fantasma, porque meu filho já não existia mais. Desde o dia 27 de abril de 2007 acabou. Acabaram com ele e colocaram um bilhete. Era alguma formação de milícia, então eles se aproveitaram pra colocar terror aqui dentro.

Em relação ao caso de seu filho, acha que o motivo do conflito que provocou seu desaparecimento e assassinato possa ser uma terra que ele possuía, onde cultivava alguns animais. Segundo Maria das Dores "as pessoas" achavam que "era muita terra pra uma pessoa criar bicho". Ela conta que "está tendo invasões" na área, mas as pessoas, quando invadiram "aquilo ali", sabiam que era de seu filho. Disse que, tempos depois, ficou sabendo que o filho vinha sofrendo ameaças de morte.

13 P2 é como é conhecido o serviço de inteligência da Polícia Militar. 


\section{0 aluguel do caveirão}

A primeira notícia Maria recebeu da irmã pelo telefone. Teria ocorrido uma operação policial na favela e alguns jovens teriam sido levados dentro do caveirão, ${ }^{14}$ entre eles seu filho. Segundo Maria, policiais teriam recebido o valor de 50 mil reais para "alugar o caveirão" a traficantes de uma facção para invadirem um território dominado por outra. Acompanhemos um trecho do relato de Maria:

Eu acordei muito cedo e não vi ele. Passei pela minha mãe direto, porque também pra não me atrasar, e fui embora. E eu fiquei o dia inteiro com aquele aperto no peito todo. Aquela coisa! Fica uma angústia, sabe? E eu ligava pra casa e ninguém atendia e ligava pra casa ninguém atendia. Aí eu me lembrei que tinha a minha irmã, pra eu ligar pra casa da minha irmã, que morava na rua de cima. Quando liguei, minha irmã falou: "Você está sentada?" E eu falei: "O que foi, Conceição, o que aconteceu? Meu coração está apertado. O que houve com o Alexandre? O que foi? Aconteceu alguma coisa com o Alexandre?" Aí ela falou pra mim assim: "Maria, o que aconteceu foi o seguinte, aconteceu uma operação dentro da comunidade e alguns meninos foram levados dentro do caveirão."

Pelo telefone Conceição disse que mandaria Manoel, o filho mais velho de Maria, até a favela, para saber o que havia ocorrido. Enquanto Manoel ia à favela, Maria foi conversar com o gerente do banco onde trabalhava e pediu para ser liberada mais cedo, porque algo de errado estava acontecendo em casa com seu filho. O gerente do banco, que, segundo Maria, era muito seu amigo, compreendeu sua preocupação e a liberou. Maria trocou de roupa para ir embora, mas antes ligou novamente para a irmã. A irmã de Maria lhe perguntou se já estava a caminho de casa e recomendou que andasse rápido, porque a informação que havia chegado era a de que Alexandre fora levado pelo caveirão e entregue aos traficantes da favela Cutelo, onde o tráfico é comandado por uma facção rival à da favela Samambaia.

Segundo os moradores ouvidos por Maria, os policiais entraram na favela Samambaia com o caveirão para dar cobertura aos traficantes da facção

14 “Caveirão" é o nome popular do carro blindado utilizado pelo Bope da Polícia Militar do Rio de Janeiro em incursões nas favelas fluminenses. 
rival que desejavam tomar as bocas da favela. Um X-915 teria se aproveitado da situação para se vingar do filho de Maria. Ela, no entanto, continuava sem entender por que levaram logo o seu filho, e continuava fazendo essa pergunta às outras mães e aos familiares dos outros jovens sequestrados. Até que obteve uma resposta mais precisa de alguém que lhe disse:

Maria, eu soube que quando o X-9 viu ele saindo de dentro da comunidade, quando o caveirão passou, o menino virou para um dos traficantes que estava dentro do caveirão, e falou assim: "Esse é da favela, filho de um dos donos da favela." Aí pararam o caveirão, e colocaram ele. Quando pegaram meu filho, diz que um dos chefes do tráfico falou o seguinte: "Ganhei na loteria, peguei o filho do cara." Aí, diz que ele ainda olhou para o meu filho e falou para o meu filho: "Nunca vi negro de nariz fino!" Porque meu filho tinha o nariz fino, mas fininho. "Nunca vi negro de nariz fino!" Diz que pegou o cortador do bolso, tirou um cortador de unha, eu não sei, e cortou um pedaço do nariz do garoto. Cortou um pedaço do nariz do meu filho. Quem conta essa história é um dos sobreviventes, um dos meninos que foi liberado, porque foram 13 sequestrados.

Dos 13 jovens sequestrados, cinco foram liberados, dos quais dois nunca foram identificados. Foram os três sobreviventes identificados que relataram a versão de que eram 13 os jovens sequestrados por traficantes da favela rival, com a participação da polícia e de um X-9. Ao tomar conhecimento de que traficantes da favela Cutelo estavam envolvidos no sequestro, Maria quis seguir para lá, porém os outros familiares não a deixaram ir. Seguraram-na dentro da favela Samambaia e depois seguiram para a delegacia de polícia.

Maria relata que olhou "na parte de cima da delegacia". Lá estava o X-9, com as mãos algemadas. Segundo ela, quando ele "bateu o olho nela", ficou "assim meio sem graça" e baixou o olhar. No entanto, quando olhava para as outras mulheres, familiares dos outros jovens, ele as ameaçava. Maria começou a se sentir mal na delegacia, mas ainda deu tempo de reconhecer dois jovens moradores de Samambaia, que também estavam na delegacia. Ao avistarem esses jovens os familiares passaram a perguntar por cada um dos desaparecidos, já que foram todos pegos juntos. Maria se dirigiu a um deles para solicitar notícias de seu filho:

${ }^{15}$ X-9: na gíria do crime significa delator, traidor, dedo-duro, informante da polícia.

Horizontes Antropológicos, Porto Alegre, ano 22, n. 46, p. 37-64, jul./dez. 2016 
Virei pra esse rapaz, que me olhava muito arregalado, e perguntei pra ele assim: "Meu filho, por favor", e peguei a foto do meu filho e mostrei pra ele. "Esse menino tava junto com vocês? Você viu se eles pegaram esse menino?" Ele ficou paralisado. Ele olhava pra mim, mas não conseguia me responder, sabe? Eu via o terror no olho dele, no rosto dele, e eu falei: "Meu filho, me responde! Esse menino tava com vocês?" E ele balançou um pouquinho a cabeça, quase não mexendo, assim pra mim, sabe? E aí ele abaixou a cabeça e a lágrima desceu no olho dele. Ai eu falei: "Meu filho, pelo amor de Deus, fala pra mim, o que foi que você viu? Esse menino tava no meio deles?" Esse menino não piscava nem nada. Ele olhava fixo dentro dos meus olhos e ele ficava paralisado assim. O olhar dele me deu medo, de desespero. Porque eu olhei pra ele e tipo como se ele não quisesse falar! Aí eu virei as costas e bati com a mão na parede e falei: "O meu filho está morto! Eles mataram o meu filho e ele viu o meu filho morrendo." Aí ele pegou e ficou assim... a lágrima dele descia. Ele abaixou a cabeça. Aí eu não via mais nada, quando eu acordei eu já estava lá dentro. Eu desmaiei e não conseguia falar. Eu fiquei oito horas sem ter voz. Fiquei paralisada, oito horas sem falar. Eu não conseguia falar uma palavra. Eu abria a boca e não saía. Eu fiquei paralisada, era como se eu tivesse tomado uma anestesia, alguma coisa, porque eu queria andar e minha perna não respondia. Aí eu fui tirada dali, me pegaram pelas pernas, me colocaram dentro de um carro e dali me levaram para um hospital, para o Getúlio Vargas.

Quando voltou a si, a peregrinação continuou por delegacias, batalhões de polícia, hospitais. No Batalhão de Polícia ouviu da boca do comandante que nenhum carro blindado havia sido liberado para participar de quaisquer operações policiais. No hospital, havia um cerco policial, ninguém entrava. Uma barreira policial foi feita, controlando a entrada no hospital. Maria tentou se comunicar com os policiais. Mostrou uma foto do filho a um policial, que levou até os demais. Segundo Maria, ao ver a foto, os policiais começaram a rir.

Com o passar do tempo várias versões circularam sobre possíveis desfechos para o caso. Entre elas a de que durante um baile funk para comemorar a "captura" dos jovens, eles teriam sido amarrados e colocados nus, e conforme o espeto do churrasco ia esquentando, os jovens seriam furados e colocados ao telefone para que os traficantes ouvissem os gritos. Dizia-se também que os jovens seriam usados como moeda de troca nos conflitos entre as facções. Também circulava o boato de os jovens tinham sidos mortos, picados e jogados para os porcos. Alguns animais chegaram a ser examinados, mas nada se comprovou. Apesar de todas as versões, Maria ainda prefere acreditar que o filho esteja vivo. Acredita que a intenção dos traficantes era apenas "tomar as bocas da área" e não sequestrar os jovens.

Horizontes Antropológicos, Porto Alegre, ano 22, n. 46, p. 37-64, jul./dez. 2016 


\section{0 ato de fazer desaparecer corpos/pessoas: um dispositivo de força entre violência estatal e criminal}

Embora não seja possível definir a abrangência do fenômeno do desaparecimento forçado de pessoas, é possível sugerir que ele corresponde hoje a um dispositivo de governo-gestão, uma tecnologia de poder praticada por diferentes atores, incluindo o Estado, através principalmente da polícia/policiais, nos territórios. O desaparecimento forçado consiste atualmente, pelo menos na região metropolitana do Rio de Janeiro, em um dispositivo de força situado entre a violência estatal e a violência criminal.

Há também um campo de continuidades que envolve, por um lado, polícia/milícia/“traficantes", no plano dos perpetradores. Por outro lado, há um universo de vítimas possíveis que têm em comum sua vulnerabilidade a esse dispositivo de gestão, pela combinação de variáveis territórios/condição social/atividade/suspeição. $\mathrm{O}$ ato de fazer desaparecer corpos, enquanto prática-evento, fornece um denominador comum para atores que geralmente são colocados como distintos ou mesmo antagônicos. Esses atores se movimentam ora "colaborativamente" ora em disputa, mas compartilham de certos entendimentos comuns (por exemplo, que algumas pessoas sejam desaparecidas/“desaparecíveis”).

Polícia, milícia e "traficantes" se aproximam ou se afastam, se combatem ou cooperam entre si, em nome de algo como o território, a autoridade, o lucro do comércio de drogas e serviços e uma diversidade de ilicitudes. Corpos e pessoas desaparecidas fazem parte da linguagem do confronto entre tais atores, podendo inclusive ser objeto de transação. Nesse sentido, o terror aparece como parte de um mecanismo de poder e não como algo que o extrapola. $\mathrm{O}$ excesso é parte de uma economia semântica, cuja linguagem pode ser dirigida ora aos próprios atores em disputa/composição, ora a segmentos de moradores de determinados territórios, ora ainda dirigido a sujeitos específicos em condições de vulnerabilidade (territórios/condição social/atividade/ suspeição).

Uma dimensão do terror que emerge nos casos de desaparecimento forçado seria aquela que se inscreve sobre os corpos virtuais: corpos que podem ter sido torturados; que podem ter sido devorados; que podem ter sido esquartejados. Mas cuja corporalidade não está materializada, porém se faz 
do rumor, dos fragmentos, da suposição. $\mathrm{O}$ excesso que o desaparecimento provoca, em termos de suspensão da vida, transforma-o em um drama não apenas para a vítima direta - o desaparecido - mas desloca-se para aqueles que sofrem por ele. Desse modo, além do morto/desaparecido, aqueles que sofrem por ele também se constroem nesse processo como vítimas.

Se durante a ditadura o desaparecimento forçado representou uma linguagem do terror de Estado praticado principalmente contra os opositores políticos (mas não só), hoje ele aparece como prática da linguagem da "violência", associado a práticas de violência policial, de grupos de extermínio, de milícias e traficantes. No quadro geral dos desaparecimentos e da "violência", o ato de fazer desaparecer corpos possui pouca visibilidade na arena pública. Seu horizonte de publicização encontra-se limitado por ser considerado pela polícia uma ocorrência sem importância e associado à inferioridade da favela e seus moradores. $\mathrm{O}$ cerceamento da palavra, a desqualificação das vítimas, de seus familiares, e seus locais de moradia, constituem um quadro que precisa ser rompido para fazer circulação da narrativa de terror dos familiares e acessar o Estado e a arena pública.

\section{Referências}

ABRAMS, P. Notes on the difficulty of studying the state. In: SHARMA, A.; GUPTA, A. (Ed.). The anthropology of the state: a reader. Oxford: Blackwell Publishing, 2006.

ARAÚJO, F.A. Das “técnicas" defazerdesaparecercorpos: desaparecimentos, violência, sofrimento e política. Rio de Janeiro: Lamparina, 2014.

BARCELLOS, C. Rota 66: a história da polícia que mata. Rio de Janeiro: Record, 2003.

BRASIL. Lei $n^{\circ}$ 9.140, de 04 de dezembro de 1995. Reconhece como mortas pessoas desaparecidas em razão de participação, ou acusação de participação, em atividades políticas, no período de 2 de setembro de 1961 a 15 de agosto de 1979, e dá outras providências. Brasília, 1995. Disponível em: <http://www. planalto.gov.br/ccivil_03/Leis/L9140.htm>. Acesso em: 28 set. 2015. 
CALVEIRO, P. O poder desaparecedor: os campos de concentração na Argentina. São Paulo: Boitempo, 2013.

CÂMARA MUNICIPAL DE SÃO PAULO. CPI Perus - Desaparecidos Políticos. Onde estão?: relatório da Comissão Parlamentar de Inquérito. São Paulo, 4 set. 1992.

CANO, I.; DUARTE, T. (Org.). “No sapatinho”: a evolução das milícias no Rio de Janeiro (2008-2011). Rio de Janeiro: Fundação Heinrich Böll, 2012.

CEFAÏ, D. Qu'est-ce qu'une arene plublique? Quelques pistes pour une approche pragmatiste. In: CEFAÏ, D.; JOSEPH, I. L'Heritage du pragmatisme: conflits d'urbanité et épreuves de civisme. La Tour D'Aigues: Editions de l'Aube, 2002. p. 51-81.

COMISSÃO NACIONAL DA VERDADE. Relatório da Comissão Nacional da Verdade. Brasília, 2014. 3 v.

DAS, V. The signature of the state: the paradox of illegibility. In: DAS, V.; POOLE, D. (Ed.). Anthropology in the margins of the state. Santa Fe: School of America Research Press, 2004. p. 225-252.

DAS, V.; POOLE, D. (Ed.). Anthropology in the margins of the state. Santa Fe: School of America Research Press, 2004.

FARIAS, J. Governo de mortes: uma etnografia da gestão de populações de favelas no Rio de Janeiro. 2014. Tese (Doutorado em Sociologia)-Instituto de Filosofia e Ciências Sociais, Universidade Federal do Rio de Janeiro, Rio de Janeiro, 2014.

FELTRAN, G. Crime e periferia. In: LIMA, R. S.; RATTON, J. L.; AZEVEDO, R. Crime, polícia e justiça no Brasil. São Paulo: Contexto, 2014. p. 299-307.

FERREIRA, L. Uma etnografia para muitas ausências: o desaparecimento de pessoas como uma ocorrência policial e problema social. 2011. Tese (Doutorado em Antropologia Social)-Museu Nacional, Universidade Federal do Rio de Janeiro, Rio de Janeiro, 2011. 
INTERNATIONAL CRIMINAL COURT. Rome Statute of the International Criminal Court. The Hague, 2011. Disponível em: <https://www.icc-cpi. int/NR/rdonlyres/ADD16852-AEE9-4757-ABE7-9CDC7CF02886/283503/ RomeStatutEng1.pdf>. Acesso em: 28 set. 2015.

LIMA, R. S. de; BORGES, D. Estatísticas criminais no Brasil. In: LIMA, R. S. de; RATTON, J. L.; AZEVEDO, R. G. de. (Org.). Crime, polícia e justiça no Brasil. São Paulo: Contexto, 2014. p. 213-226.

MISSE, M. Malandros, marginais e vagabundos: a acumulação social da violência no Rio de Janeiro. 1999. Tese (Doutorado em Sociologia)-Instituto Universitário de Pesquisas do Rio de Janeiro, Rio de Janeiro, 1999.

MISSE, M. et al. Quando a polícia mata: homicídios por "autos de resistência" (2001-2011). Rio de Janeiro: CNPq: Necvu: Booklink, 2013.

MOLINA THEISSEN, A. L. La desaparición forzada de personas en América Latina. Ko'ãg̃a Roñe'êtã, serie vii, 1998. Disponível em: <http://www. derechos.org/koaga/vii/molina.html>. Acesso em: 5 jun. 2011.

OLIVEIRA, D. D. de. O desaparecimento de pessoas no Brasil. Goiânia: Cânone Editorial, 2012.

ORGANIZAÇÃO DOS ESTADOS AMERICANOS. Convenção Interamericana sobre o Desaparecimento Forçado de Pessoas. Belém do Pará, 1994. Disponível em: <http://www.oas.org/pt/cidh/mandato/Basicos/ desaparicion.pdf $>$. Acesso em: 28 set. 2015.

TELLES, V.; HIRATA, D. Cidade e práticas urbanas: nas fronteiras incertas entre o ilegal, o informal e o ilícito. Estudos Avançados, São Paulo, v. 21, n. 61, p. 173-191, 2007.

UNITED NATIONS. General Assembly. Declaration on the Protection of All Persons from Enforced Disappearance. 18 Dec. 1992. Disponível em: $<$ http:// www.un.org/documents/ga/res/47/a47r133.htm>. Acesso em: 28 set. 2015. 
VIANNA, A. Violência, Estado e gênero: considerações sobre corpos e corpus entrecruzados. In: SOUZA LIMA, A. C.; ACOSTA, V. G. (Org.). Margens da violência: contornos estatais e sociais do problema da violência nos contextos mexicano e brasileiro. São Paulo: ABA, 2013. p. 209-237.

ZACCONE, O. Indignos de vida: a forma jurídica da política de extermínio de inimigos na cidade do Rio de Janeiro. Rio de Janeiro: Revan, 2015.

Recebido em: 30/09/2015

Aprovado em: 09/03/2016 